\title{
YWHAZ Gene
}

National Cancer Institute

\section{Source}

National Cancer Institute. YWHAZ Gene. NCI Thesaurus. Code C88202.

This gene is involved in both interactions with phosphoproteins and signal transduction. 